\title{
The influences of the type of information on the purchase intention and performance expectation of residential real estate properties
}

\author{
Influências do tipo de informação na intenção de compra \\ e expectativa de desempenho de imóveis
}

\section{Francieli Vargas Dalbosco \\ Elvira Maria Vieira Lantelme \\ Eduardo Rech}

\begin{abstract}
D

uring the Purchase Decision Process (PDP), consumers use limited information to evaluate the value of an asset, considering that they do not have access to complete and adequate information, lack of knowledge and experience. Technical information about building performance can be used as differential attributes in the PDP. This research seeks to analyze the influence of technical information on the purchase intention and performance expectations of residential real estate consumers. Two studies were conducted, with different but complementary characteristics, the first one being exploratory and qualitative and the second one being experimental and quantitative. The results showed that information, regardless of its content and format, has a significant impact both on purchase intention and performance expectation when provided to the consumer during the purchasing process. However, the information content and format as used in the advertisements developed for this study's experiment showed no significant differences in the variables analyzed. The main contribution of this work is to provide subsidies to improve the adaptation of real estate marketing advertisements and guarantee better and qualified information to consumers.
\end{abstract}

Keywords: Real Estate Market. Technical information. Purchase intention. Performance expectation. NBR 15575.

\section{Resumo}

Durante o Processo de Decisão de Compra (PDC) de imóveis, os consumidores usam informações limitadas para avaliar o valor de um imóvel, em razão de não terem acesso a informações adequadas e completas e por falta de conhecimento e experiência. Assume-se que informações técnicas sobre os requisitos de desempenho do imóvel poderiam compor atributos diferenciais no PDC. Esta pesquisa analisou a influência das informações

${ }^{1}$ Francieli Vargas Dalbosco ${ }^{1}$ MMED - Politécnica Passo Fundo - RS - Brasil

${ }^{2}$ Elvira Maria Vieira Lantelme 2IMED - Politécnica Passo Fundo - RS - Brasil

${ }^{3}$ Eduardo Rech ${ }^{3}$ IMED - Business School Passo Fundo - RS - Brasi

Recebido em 02/11/20 Aceito em 17/02/21 técnicas na intenção de compra e expectativa de desempenho do consumidor. Dois estudos foram realizados com características distintas e complementares, sendo o primeiro exploratório e qualitativo e o segundo, experimental e quantitativo. Os resultados comprovaram que fornecer informações ao consumidor no processo de aquisição de um imóvel impacta significativamente na intenção de compra e expectativa de desempenho. No entanto, o conteúdo e formato da informação, como utilizada nos anúncios desenvolvidos para esta pesquisa, não apresentou influência significativa nas variáveis analisadas. A principal contribuição desta pesquisa é prover subsídios para melhor adequação dos anúncios de imóveis e, consequentemente, garantir informações de qualidade ao consumidor.

Palavras-chave: Mercado Imobiliário. Informações técnicas. Intenção de Compra. Expectativa de desempenho. NBR 15575. 


\section{Introduction}

The real estate market has great influence in the economy, contributing to the growth and development of a city, due to its ability to generate jobs and income (PAZ; NOBRE; NOBRE, 2020). The real estate market is associated with the set of activities related to the construction of buildings, and also with the production of construction materials, real estate activities such as brokerage and insurance, property management, buying, selling and renting, and building maintenance activities (WISSENBACH, 2008; ALMEIDA; BOTELHO, 2008).

Understanding the real estate market and the elements that define buyers' choices regarding their new home is a task that requires effort and care, especially because of the different housing standards that exist in a market. The market for affordable housing, for example, may have different decision factors than the market for premium quality housing (OLANREWAJU; WOON, 2017).

The property - the product of the real estate market - "[...] is unique and non-serial, with a permanent location, which hinders the consistency of processes and all the other aspects that involve its production [...]" (NOBRE; SANTOS; BARROS NETO, 2004, p. 2.720). Dantas (2000) classifies real estate property as a durable, tangible good when construction is finished and intangible when it is still under construction. As such, it has several attributes that generate a greater involvement of the consumer in the purchasing process (CAMPOS JÚNIOR; INFANTE; ALEXANDRE, 2008).

For purchases of products with a high monetary value and high involved risk, such as residential real estate, consumers engage in a long time search and use multiple sources of information, involving a learning process about the product (CAMPOS JÚNIOR; INFANTE; ALEXANDRE, 2008). The purchase decision process of a property, therefore, tends to be made by comparing attributes during which the technical aspects of the property tend to become relevant (PACANHAN et al., 2004).

Information about the quality and performance of a property at the time of sale is a fundamental right of the consumer, mentioned in the Brazilian Consumer Defense Code (BRASIL, 1990), in addition to being part of the requirements appearing in the Brazilian Performance Standard (Norma Brasileira de Desempenho, NBR 15575:2013 (ABNT, 2013)). The delivery of complete and correct information to buyers provides greater security regarding the investment (WONG et al., 2018).

In this regard, Gong, Lizieri, and Bao (2019) mention that, in the U.S., the disclosure of products and services in many industries is required by federal law and regulations, enabling the release of information in an efficient manner, ensuring accessibility and ease of use by the public. In the UK, the government has been carrying out programs to provide individuals with access to information, empowering consumers in the decision-making process.

To reduce the ambiguity and uncertainty faced by real estate consumers, a way of communicating and spreading information must be established in the buying process by real estate professionals (GONG; LIZIERI; BAO, 2019). Given this scenario, it is assumed that the technical information about the performance requirements of the property, present in the Brazilian Performance Standard (NBR 15575: 2013), could be valuable attributes in the purchase decision.

The Brazilian Performance Standard (ABNT, 2013), established the performance and quality of buildings by defining user requirements, criteria and evaluation methods, which enabled the objective measurement of their compliance. These requirements represent a set of conditions for the well-being of buildings' users (OKAMOTO, 2015; GOMES, 2015; MARTINS et al., 2013).

In addition, it is crucial that such information is arranged in a clear and accessible way to buyers during the information search processes. This is because, when it comes to technical information, language can become an obstacle in the communication process. Although buying real estate property is a high-involvement purchase (KOKLIC; VIDA, 2009), where the buyer tends to immerse in the process, many technical terms remain inaccessible.

In order to contribute to the access and quality of information available to the residential real estate buyer, this study asked the following guiding question: does the technical information of a real estate property influence the purchase intention and performance expectation of the consumer? The objective of this research was to analyze the influence of technical information on the consumer's purchase intention and performance expectation. To achieve the objectives, a research plan was conceived consisting of two studies with distinct but complementary characteristics, the first being exploratory and qualitative, and the second being experimental and quantitative. 
In the expectation of bringing contributions to those involved in the buying process in the real estate market, this study investigated the influence of the technical information of a property, referring to the Brazilian Performance Standard (ABNT, 2013), when provided through advertising material to consumers in the real estate market. To this end, different forms of presenting this information were investigated in order to verify if, besides its presence, the language adopted in the technical information exerts influence on the consumer's purchase intention and performance expectation regarding the property.

\section{Consumer behavior in the real estate market}

Consumer behavior is a decision-making process that has been an important research topic in the field of marketing, which not only studies consumers' behavior, but also the factors that influence it (GUIMARÃES FILHO, 2019; KOKLIC; VIDA, 2009). The decision process models developed by researchers based on the Howard and Sheth (1969) model, act as a mental map of the individual, which can be used by marketing professionals as a guide in the development of products and communication and sales strategies.

Furthermore, investigating decisions that can change consumers' lives, such as the purchase of real estate, can generate important contributions to the body of knowledge in consumer behavior in the real estate market (KOKLIC; VIDA, 2009). A common characteristic of durable goods, such as real estate, is that the purchase decision is complex, especially when the price is perceived as high (KOKLIC; VIDA, 2009) and when there are significant differences between the products offered in the market (CAMPOS JÚNIOR; INFANTE; ALEXANDRE, 2008). This leads to longer negotiation processes and requires knowledge, which often are not necessary for the purchase of other products (GUIMARÃES FILHO, 2019).

Due to the similarity of Purchase Decision Process (PDP) models, the simplified five-step model is the most accepted among authors, and it is used as the theoretical framework of this study (SOLOMON, 2016; KOTLER; KELLER, 2006; MOWEN; MINOR, 2003; PACANHAN et al., 2004). This model is based on a five-step decision process, namely:

(a) recognition of the need or problem;

(b) followed by the internal and external search for information;

(c) evaluation of alternatives;

(d) purchase decision; and

(e) post-purchase behavior.

The current study focuses mainly on the second and third steps: search for information and evaluation of alternatives.

The search for information, is the stage in which the consumer begins to seek information about existing properties in the real estate market to reduce the perceived risks associated with the purchase process. It occurs in two ways: internally and externally (SOLOMON, 2016).

As such, the purchase of a property can be considered a strategic purchasing decision, because it involves a lot of information gathering (ZAKARIA et al., 2015). This information gathering can range from a simple memory probe (internal search) to extensive fieldwork (external search), consulting with reference groups and communication tools (SOLOMON, 2016).

Currently, real estate agents and brokers use communication techniques such as social media to improve brand visibility and enable better performance in the real estate market (BABATUNDE; AJAYI, 2018). Today, therefore, consumers of the real estate market start their search on the Internet, using real estate websites and social networks, in addition to searching for brokers to find the ideal property (GUIMARÃES FILHO, 2019).

As such, consumer choices in the real estate market are made based on individual values and previous personal experiences (OLIVEIRA; HEINECK, 1999), as well as within the framework of preferences and attribute choices (ZINAS; JUSAN, 2012). Consumer preferences and attitudes in the real estate market are influenced by factors in the purchase process, such as: life cycle, lifestyle, income, employment, housing policy, economic factors (price and financing conditions), internal and external attributes of the property, among others (CLARK; LISOWSKI, 2017; GONZAGA, 2003).

The properties, which are the product of the real estate market, have several attributes classified according to their characteristics. However, the conceptual framework of this study is specifically focused on the analysis 
of the effect of technical information related to user requirements present in the Brazilian Performance Standard (ABNT, 2013).

Based on these information sources, consumers identify the existing products in the real estate market and evaluate the alternatives. This step is called alternative evaluation (third step of the PDP), which involves the weighing of characteristics and attributes to establish which are important and indispensable to meet their needs and bring benefits (SOLOMON, 2016; MOWEN; MINOR, 2003). In the alternative evaluation step, the consumer compares the options found and forms the purchase intention (BLACKWELL; MINIARD; ENGEL, 2005) and the performance expectation for the product.

Purchase intention, therefore, was considered in this study as one of the dependent variables. This variable represents the combination of the consumer's interest in buying a certain product with the possibility of that purchase occurring (WU et al., 2015); that is, it represents the motivation that the consumer has to actually make a purchase in the future (REZVANI et al., 2012).

Purchase intention is positively influenced by some independent variables, such as brand image, item quality, product knowledge, engagement, attributes, and brand loyalty (TARIQ et al., 2013). Tariq et al. (2013) state that product quality parameters are key factors in measuring purchase intention, turning it into a continuous improvement process to increase product performance and satisfy customer needs.

Product performance expectation, in turn, is generated in the steps prior to the purchase and reflects the expected performance of the product (CHURCHILL; SURPRENANT, 1982; PANSARI; KUMAR, 2017). It was considered in this study as the second dependent variable. Expectations reflect the anticipated performance of the product (MACHADO, 2005) and create a frame of reference based on which a comparative judgment is made (OLIVER, 1980, 1993).

When the purchase of a property takes place, this is followed by the post-purchase evaluation, i.e., a cycle is closed and the satisfaction regarding the product is formed (SOLOMON, 2016). Satisfaction derives from the proximity between the consumer's initial expectations in the decision process and the perceived performance of the property in the use phase, and it plays an important role in future consumer behavior (SOLOMON, 2016). If the performance does not meet expectations, the consumer will be disappointed and dissatisfied (KOTLER; KELLER, 2006).

\section{Technical information of a property}

The intrinsic quality of a property implies in a set of elements, such as the absence of defects, errors or flaws, and the presence of characteristics that interest the customer, reliability and predictability, among others. That is, it is a precise and measurable variable, arising from the product attributes (ALVARENGA; ZANQUETTO FILHO, 2015; ALMEIDA; TOLEDO, 1992).

The act of informing modifies the consumer's knowledge, decreasing uncertainties with the purchase and, consequently, changing their behavior towards the product (BUCKLAND, 1991). In this sense, Wong et al. (2018) identify that there is a disadvantage in the fact that buyers do not have access to more technical information, such as information about sustainability and performance, generating what they call information asymmetry between the sellers and buyers of residential properties (TAVARES; MOREIRA; PEREIRA, 2013).

It is assumed that well-informed consumers will not be deceived by dishonest companies that distort the relationship between price and quality of the properties offered in the real estate market. When consumers purchase a property in the real estate market, therefore, they must be assured of their right to information about the attributes related to the property before the purchase.

By itself, information has no value, since it is through its use within a certain context that conclusions can be generated to improve processes or make decisions. The right to information is directly linked to the principle of transparency (art. 4, caput, Brazilian Consumer Code, CDC), which translates into the supplier's obligation to give the consumer the opportunity to get to know the product in advance and, at the time of purchase, to be fully aware of its content.

The right to adequate, clear and accurate information about the product placed on the market, including its characteristics, qualities and risks, constitutes a basic right and fundamental principle of the consumer, according to Law No. 8.078 (BRASIL, 1990, p. 2). In this sense, article 6, item III, of the CDC is considered to be one of the most important for the real estate market. It is related to the obligation to provide accurate

370 Dalbosco, F. V.; Lantelme, E. M. V.; Rech, E. 
and complete information about the property on offer that may influence the intention of the interested party in acquiring the unit.

Within the same scope, Siqi, Hongyu and Lee (2006) emphasize that the real estate market has a scarcity of information about product characteristics when compared to other goods. Engineering information is a specific set of information used in the organizational context and it is also called technical product information (FORNECK et al., 2011). In the context of the real estate market, a property comprises a specific set of information, such as: designs, lists of materials, technical specifications, manufacturing processes, among others.

Following this line of reasoning, this work is focused on the set of information present in the Brazilian Performance Standard (Norma de Desempenho de Edificações Habitacionais, NBR 15575 (ABNT, 2013)), which will be called technical information. The user requirements established in the Brazilian Performance Standard (ABNT, 2013) are related to safety, habitability, and sustainability, and are divided into 12 requirements:

(a) structural safety;

(b) fire safety;

(c) safety in use and operation;

(d) watertightness;

(e) thermal performance;

(f) acoustic performance;

(g) lighting performance;

(h) health, hygiene, and air quality;

(i) functionality and accessibility;

(j) tactile and anthropodynamic comfort;

(k) durability and maintainability; and

(1) environmental suitability.

\section{Research method}

This study adopted an experimental strategy to understand whether a property's technical information influences consumer purchase intention and performance expectation. This type of research, used to investigate consumer behavior in the field of marketing, requires a homogeneous group of people who are subjected to different treatments to identify the factors that contribute to the occurrence of the phenomena or variables that affect the process.

In the expectation of bringing contributions to those involved in the buying process in the real estate market, this study sought to verify and measure the existing relationships between the technical information of a property, when provided through advertising material during the sale, with the consumer's purchase intention and performance expectation.

To achieve the established objectives, a research plan was designed consisting of two studies, the first was considered in the study as an Exploratory Study and the second as an Experimental Study.

\section{Exploratory study}

The first stage of this study involved an exploratory study that sought to understand the behavior of respondents in the different stages of the Purchase Decision Process (PDP) of a real estate property in order to list information for the construction of the experimental scenarios of the main study.

The study approach was characterized by a qualitative study using semi-structured interviews, conducted from a script with questions previously defined by the researchers. The questions first focused on demographic data of the respondent and information about the purchased property. They were then directed to the description of how the five steps of the buying process were taken, especially regarding the information search, alternative evaluation and post-purchase evaluation steps, the problems found in the 
property after use, and the consumer's knowledge about technical information and the Brazilian Performance Standard (ABNT, 2013).

In this study, consumers in the real estate market were considered to be all those who had income and were able to make the purchase. The target audience for the interviews was therefore formed conveniently through the contacts with people close to the authors, or through indications by the respondents themselves. The study did not make any distinction as to the type of property, because it considered as technical information the user requirements present in the Brazilian Performance Standard (ABNT, 2013), which define the minimum performance levels regardless of the employed materials and construction methods.

The number of respondents was defined by saturation (RIBEIRO; SOUZA; LOBÃO, 2018), when the respondents' answers started to become repetitive and added little to the already-obtained information. The sample was formed by 9 consumers, including men and women, aged 24 to 53 years, who bought real estate and were in the use phase, with the amount invested ranging from 90 to 850 thousand BRL.

All the interviews were recorded with the respondents' verbal permission, and later transcribed for data analysis. The qualitative data analysis was performed for the groups individually and by cross-checking the perceptions of the interviewees based on two categories of analysis: benefits or importance of the technical information and forms of communication with the end user.

\section{Experimental study}

The second study is considered the main study. It is of an explanatory (causal) nature and was developed using a quantitative approach. As such, a consumer behavior study was performed in the real estate market using an experiment to verify the effect of the independent variable, manipulated in an advertisement, on the dependent variables, which are the purchase intention and performance expectation of a real estate property.

Regarding the experiment design, the Between-Subjects Design was employed, characterized by exposing the treatment (in this case, the technical information of the property) to different sample groups, in which the participant receives only one stimulus in isolation from the others. The experiment had an independent variable, the technical information, which was manipulated and presented in different ways, creating scenarios.

By manipulating the independent variable of the experiment, the technical information, four ads were therefore created for a fictitious property according to the standards of the real estate market. The ad design was created by the researchers themselves, with the collaboration of advertising professionals, using neutral colors and without presenting images of building common areas, the price and the size of the property, in order to prevent these attributes from influencing the answers of the respondents. The four ads created have the following characteristics.

(a) Ad 01: no information (considered as the control): conveying only the product (property), without the characteristics or information of the property (Figure 1);

(b) Ad 02: technical Information: conveying the property with technical characteristics (information), described in the same way as they are presented in the Brazilian Performance Standard (ABNT, 2013) (Figure 2);

(c) Ad 03: simplified technical information: conveying the property with the same technical characteristics (information) described in Ad 02, but now translated for the consumer, i.e., using everyday language, more familiar to the lay consumer (Figure 3); and

(d) Ad 04: market information: conveying the property with characteristics of the real estate market, i.e., the usual information in advertisements (Figure 4).

The survey was answered anonymously between December 2019 and January 2020 using the Qualtrics Research Suite (http://www.qualtrics.com/) online tool. The questionnaire generated on the Qualtrics platform was the same for the 4 manipulation groups, starting with the presentation and instructions of the survey, followed by the presentation of the fictitious property ad. After the respondent had analyzed the ad for as long as necessary, questions were asked about the dependent variables (purchase intention and performance expectation), immediately followed by control questions and, finally, demographic questions. 
Figure 1 - Ad 01 - No information

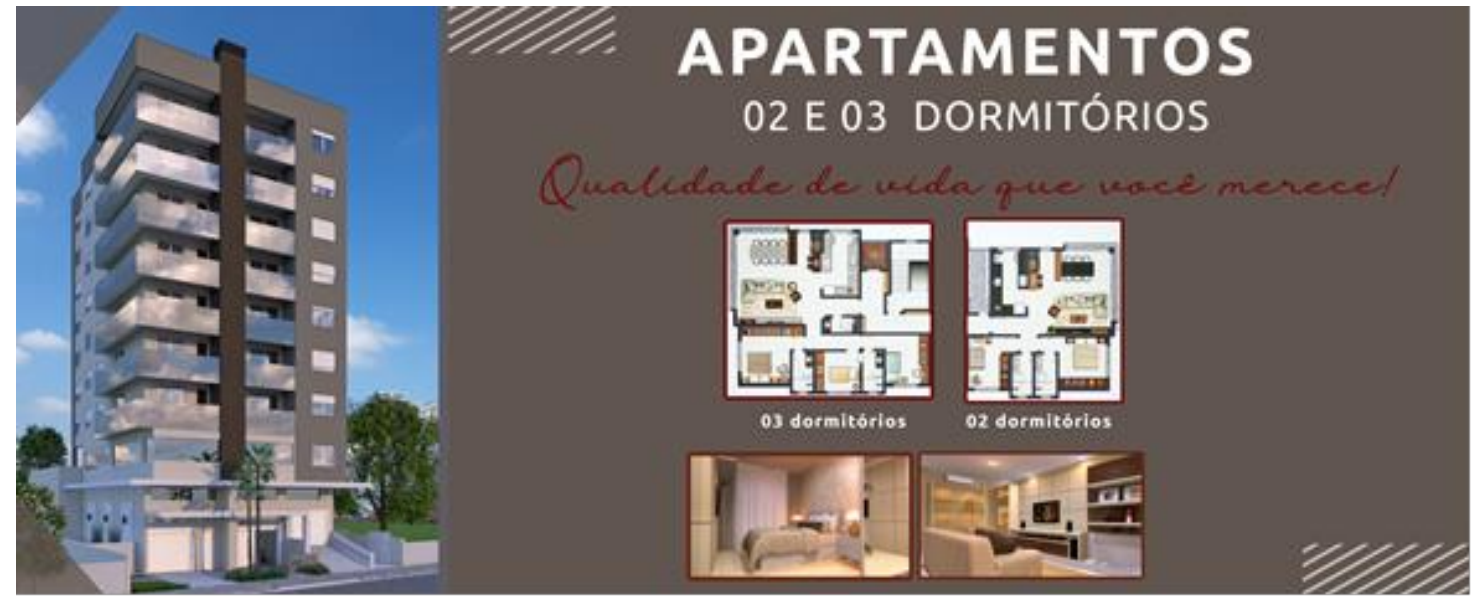

Source: research data.

Figure 2 - Ad 02 - Technical information

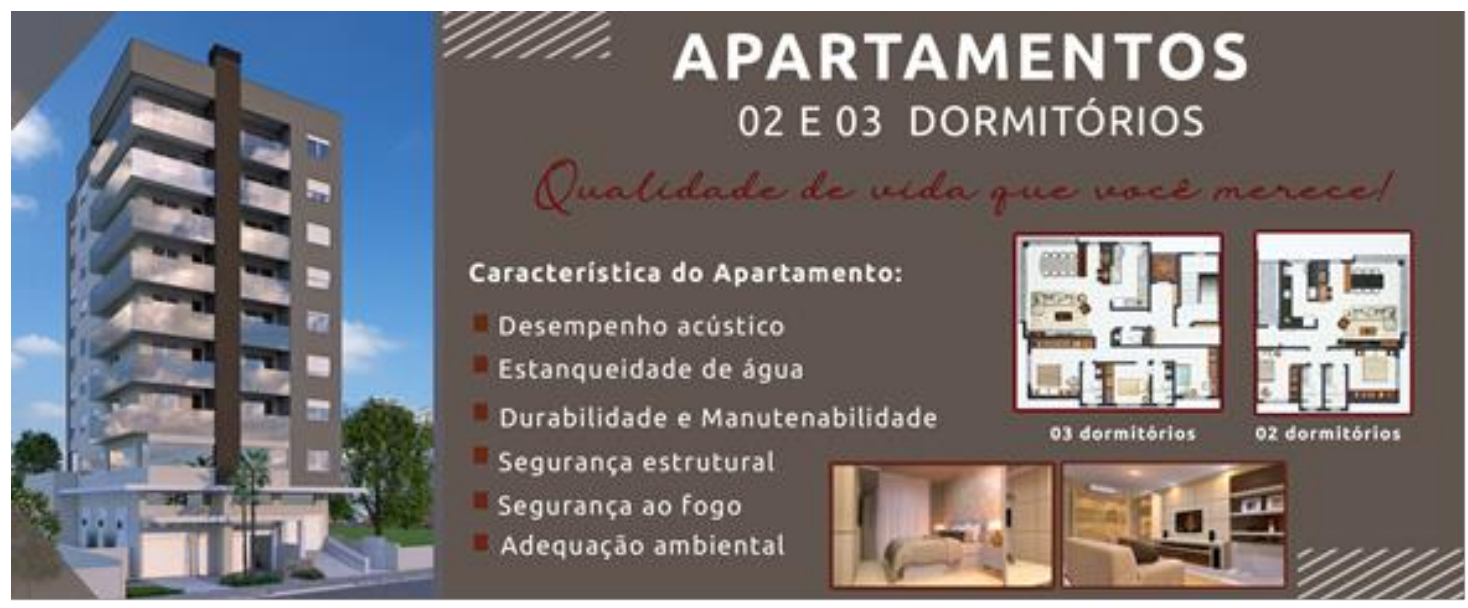

Source: research data.

Figure 3 - Ad 03 - Simplified technical information

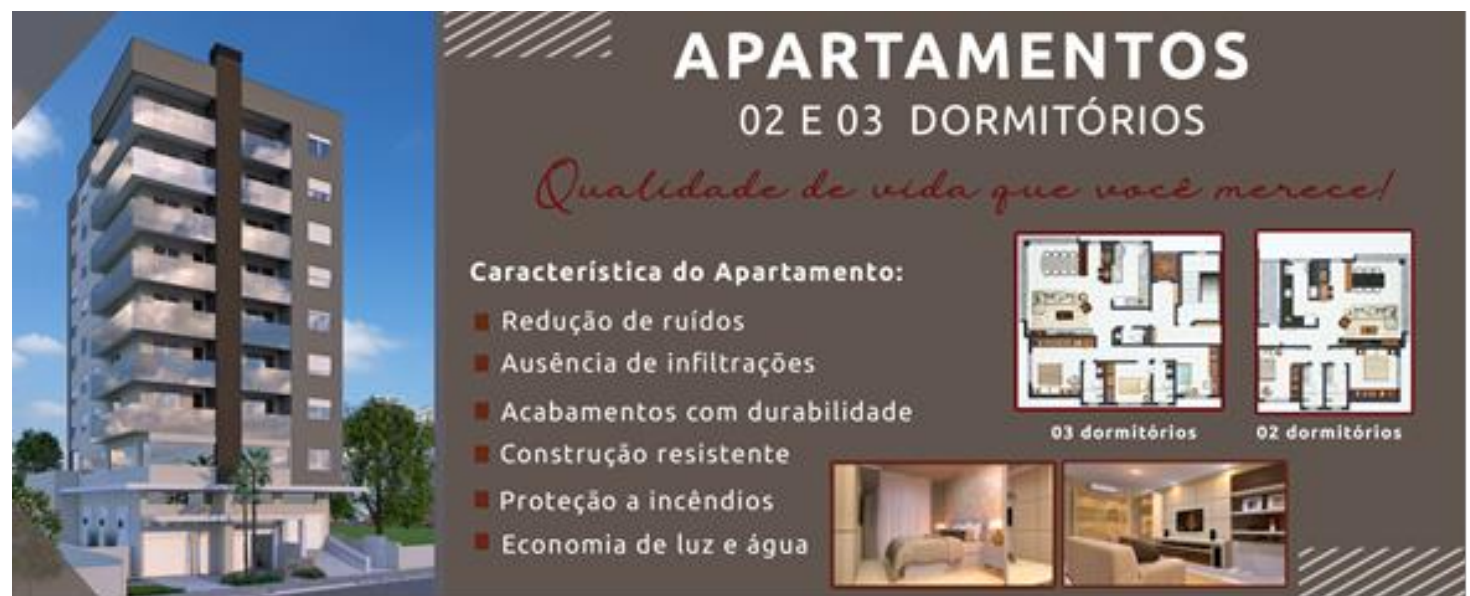

Source: research data. 
Figure 4 - Ad 04 - Market information

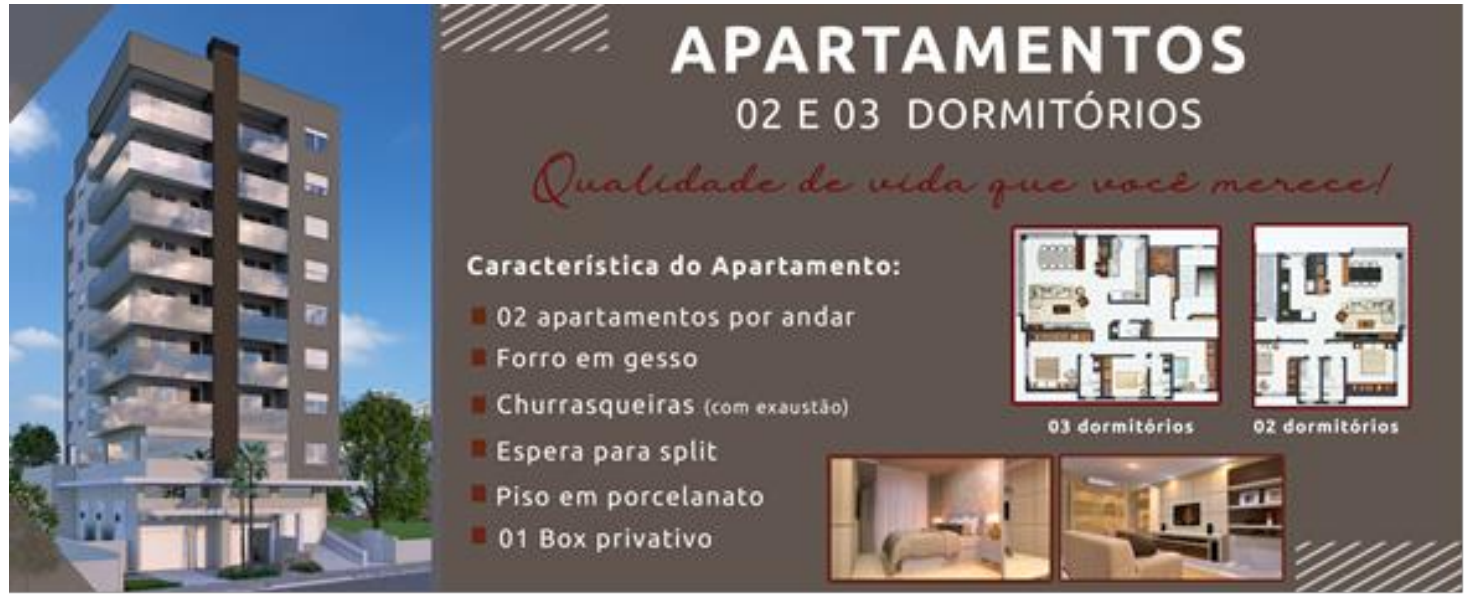

Source: research data.

The dependent variables were included in the questionnaire by means of multiple-item, five-point semantic differential scales. The dependent variables included the purchase intention, selected based on the study by Dodds, Monroe, and Grewal (1991), and the performance expectation, adapted from Block and Kramer (2009) and Patterson (1993).

This study considered to be consumers in the real estate market all those who had income and were able to make the purchase. As such, these consumers were chosen by convenience, using social media platforms like Facebook and Instagram, reaching 45\% ( $\mathrm{n}=115)$ of respondents in Passo Fundo (Rio Grande do Sul, Brazil), and 55\% $(n=139)$ in other cities in Brazil.

The total number of respondents was 268 , but 14 cases were removed when considering the 26-minute time limit to answer the survey. If this time limit was exceeded, it was assumed that the respondent would no longer remember the ad or the intent of the survey, and these responses were therefore excluded from the sample. The valid sample consisted of 254 cases, 52\% $(n=132)$ men, $47.6 \%(n=121)$ women, with one respondent who preferred not to identify gender. The mean age was 34 years $(\mathrm{SD}=11.032)$.

Regarding the profession of the respondents, they were grouped into two groups: professions that are related to the real estate market (such as brokers, builders, architects and engineers), with $24 \%(n=61)$ of the cases, and those that are unrelated, with $76 \%(\mathrm{n}=191)$.

There was a relative equilibrium between the size of the respondent groups for each of the 4 ads, since $27.6 \%(n=70)$ of respondents participated by analyzing ad 01 (control), 24.8\% ( $n=63)$ analyzed ad 02 (technical information), 25.6\% $(\mathrm{n}=65)$ analyzed ad 03 (translated technical information), and 22\% $(\mathrm{n}=56)$ analyzed ad 04 (market information).

\section{Results and discussion}

\section{Exploratory study}

The first study was an exploration to obtain a better understanding of the Purchase Decision Process (PDP) of a real estate property, mainly in the information search, alternative evaluation and post-purchase evaluation steps. In the information search step, the consumers were asked if they sought out technical information about existing products in the market before making the purchase, and in the alternative evaluation step, the dependent variables of the experimental study, the purchase intention and the performance expectation, were evidenced.

In turn, the analysis of the interviews with real estate buyers revealed two patterns of behavior in the initial stage of the buying process: buyers who perform an initial online research of properties before going to a real estate agency and buyers who search directly for real estate agents or brokers they trust. In both cases, the information researched was price, location and some building design characteristics (like number of bedrooms and bathrooms, common use areas, garage, among others). 
In general, the respondents reported that "they did not have access to the technical information of the surveyed properties". Only one of the interviewees stated that "he has the habit of seeking technical information for all his purchases". The interviews also revealed that buyers with some negative buying experience when purchasing real estate were more interested in this type of information as a way of decreasing the perceived risk.

In the respondents' opinion, the lack of technical information about the property makes it difficult to search online and to compare the properties on the market, as it is impossible to differentiate the quality of the properties. The lack of information generates a biased decision that gives rise to insecurity regarding the quality on the part of the consumer, as it has been reported in the literature (ALVARENGA; ZANQUETTO FILHO, 2015; GONG; LIZIERI; BAO, 2019).

A difference in the profile of consumers could be seen, with some being very interested in learning and lowering the perceived risk for a next purchase, and others having little such interest and being satisfied with the knowledge they have. Those who are not interested in more knowledge are those who have not yet had any negative buying experience with the lack of information.

In the alternative evaluation stage, all respondents reported that they "[...] had no concern about the quality of the property they were buying [...]". The interviewed consumers evaluated the alternatives found in the real estate market by comparing the attributes provided, only taking into account the information available, as reported by Pacanhan et al. (2004) in their research.

When asked about problems found in the properties after moving in, the respondents reported that "[...] the biggest problems were the incidence of fissures, problems with acoustic insulation between slabs, generating impact noise, problems with the watertightness of the external walls, resulting in humidity and infiltrations, and the dubious quality of the finishing materials.".

When the respondents were then asked if, in the future, they would be more careful with technical information at the time of sale, especially the care with quality, they mostly answered that "[...] they would, especially the acoustic performance requirement and the quality of the materials used in construction [...]".

The last question in the interview was whether the respondents were acquainted with the Brazilian Performance Standard (ABNT, 2013), and all reported "not knowing it". However, when the purpose of the standard was explained, some remembered that they received a "User's Manual", a document provided by the construction companies upon delivery of the property containing some of the standard's information, and they were very interested to know more.

Through the exploratory study, it was found that the respondents lacked knowledge about the product they were buying, but were very interested in more information for their next purchase. The problems found in the properties reported by the respondents are part of the user requirements present in the Brazilian Performance Standard (ABNT, 2013) and were interpreted and used in the experimental study, as described below.

\section{Experimental study}

Based on the four scenarios, that is, the four manipulated experimental groups of the independent variable (the technical information of a property), this study sought to test how much this information impacts the purchase intention and performance expectation of the real estate market consumer. An Analysis of Variance (ANOVA) with Tukey's Post Hoc test and Analysis of Covariance (ANCOVA) were used to analyze the data. ANCOVA was used to control for the effects of the control variables.

The experiment data were analyzed using the statistical software SPSS (Statistical Package for the Social Science), and the first step was to calculate Cronbach's alpha coefficient in order to analyze the reliability of the scales used: purchase intention and performance expectation. As such, all measured dimensions resulted in a satisfactory level of reliability and the analysis of covariance (ANCOVA) did not point to any significant effect of the study's control variables $(\mathrm{p}>0.05)$.

The mean responses of the dependent variables (purchase intention and performance expectation) were then calculated for the four experimental groups of the independent variable. First, a general comparison of the sample was made between the purchase intention means of the four manipulated scenarios of the independent variable. Next, the performance expectations mean of the four experimental groups were compared. 


\section{Purchase intention}

The analysis of variance (ANOVA), presented in Table 1, showed a significant difference between the means of the experimental groups for the dependent variable purchase intention $(F(3.242)=3.996)$; $(\mathrm{p}<0.05)$.

The post-hoc Tukey test was used to analyze the difference between the experimental groups, and differences between the means were found (see Figure 5). The purchase intention was higher when simplified technical information $(\mathrm{M}=4.02 ; \mathrm{SD}=0.841)$ and market information $(\mathrm{M}=3.94 ; \mathrm{SD}=0.813)$ were presented in comparison with the group in which no information was presented $(\mathrm{M}=3.54 ; \mathrm{SD}=1.028)$; $(\mathrm{p}<0.05)$. There was no significant difference in purchase intention between the information conditions (technical information, simplified technical information and market information).

\section{Performance expectation}

The effect of the independent variable, presented in Table 2, pointed to significant differences between the conditions for the dependent variable performance expectation $(F(3.242)=5.719)$; $(p<0.05)$.

The post-hoc Tukey test was used to analyze the difference between the experimental groups, and differences between the means were found (see Figure 6). The performance expectation was higher when technical information $(\mathrm{M}=4.38 ; \mathrm{SD}=0.613)$, simplified technical information $(\mathrm{M}=4.45 ; \mathrm{SD}=0.728)$ and market information $(\mathrm{M}=4.34 ; \mathrm{SD}=0.668)$ were presented in comparison with the group in which no information was presented $(\mathrm{M}=3.97 ; \mathrm{SD}=1.884 ; \mathrm{p}<0.05)$. There was no significant difference in performance expectation between the conditions with technical information, simplified technical information, and market information.

Table 1 - Results of the Analysis of Variance (ANOVA) for the purchase intention variable

\begin{tabular}{c|c|c}
\hline & F & SIG. \\
\hline Between experimental groups & 3.996 & 0.008 \\
\hline
\end{tabular}

Source: Data Collection (2019).

Figure 5 - Difference in the means between the experimental groups for the variable Purchase Intention

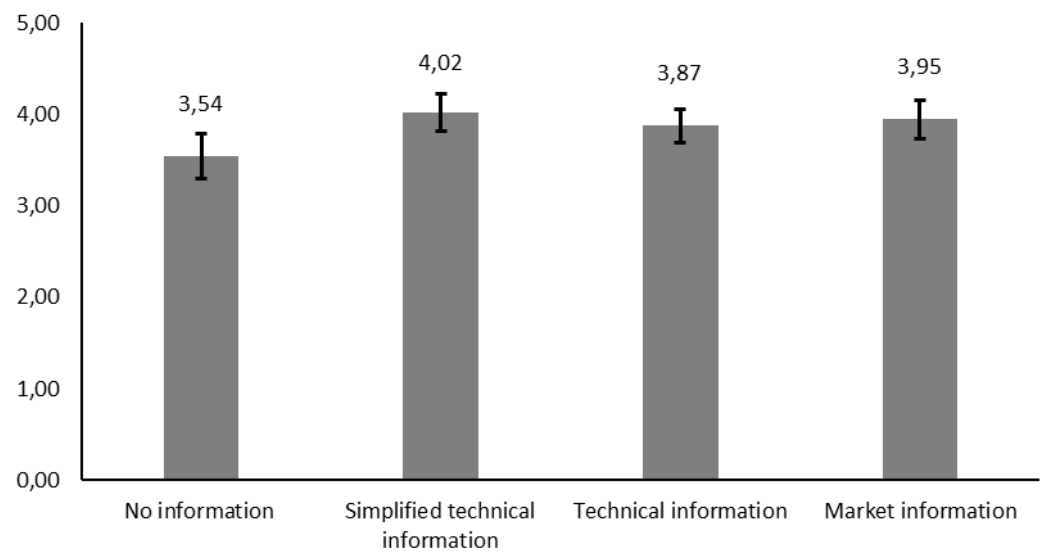

Table 2 - Results of the Analysis of Variance (ANOVA) for the performance expectation variable

\begin{tabular}{c|c|c}
\hline & F & SIG. \\
\hline Between experimental groups & 5.719 & 0.001 \\
\hline
\end{tabular}


Figure 6 - Difference in the means between the experimental groups for the variable Performance Expectation

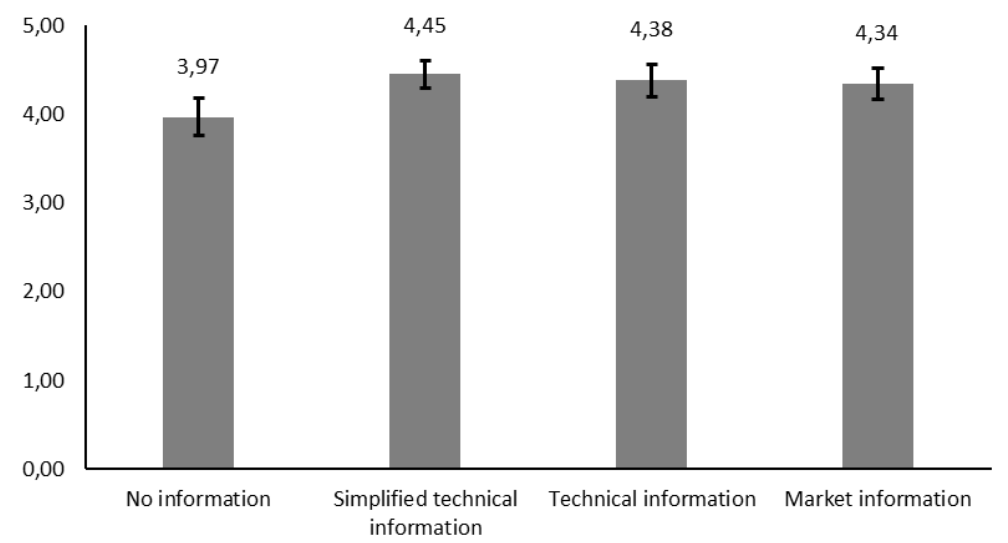

The performance expectation related to the property was also considered through six different dependent variables:

(a) less noise from neighbors;

(b) there will be no leaks;

(c) highly durable finishing;

(d) the construction will be sturdy and solid;

(e) it will be fire resistant; and

(f) it will be efficient, saving on light and water.

Three of these variables had a significant difference $(p<0.05)$ between conditions:

(a) there will be less noise from neighbors;

(b) there will be no leaks; and

(c) the finishing will be highly durable. Statistical results are shown in Table 3.

The performance expectation in relation to the dependent variable "less noise from neighbors", shown in Figure 7, was higher when technical information $(\mathrm{M}=4.02 ; \mathrm{SD}=1.024)$, simplified technical information $(\mathrm{M}=4.14 ; \mathrm{SD}=0.882)$ and market information $(\mathrm{M}=3.79 ; \mathrm{SD}=0.868)$ were presented when compared to the group in which no information was presented $(\mathrm{M}=3.24 ; \mathrm{SD}=1.055 ; \mathrm{p}<0.05)$. There was no significant difference in performance expectation between the conditions in which technical information, translated technical information, and market information were presented.

Regarding the expectation in relation to the variable "there will be no leaks", shown in Figure 8, the performance perspective was higher when technical information $(\mathrm{M}=4.10 ; \mathrm{SD}=0.911)$ and simplified technical information $(\mathrm{M}=4.02 ; \mathrm{SD}=0.893)$ was presented when compared to the group in which no information was presented $(\mathrm{M}=3.54 ; \mathrm{SD}=1.017)$; $(\mathrm{p}<0.05)$.

Finally, the performance expectation in relation to the variable "high durability finishing", shown in Figure 9, was only higher when translated technical information $(\mathrm{M}=4.25 ; \mathrm{SD}=0.708)$ was presented when compared to the group in which no information was presented $(\mathrm{M}=3.73 ; \mathrm{SD}=0.962 ; \mathrm{p}<0.05)$.

It is important to mention that there were no significant differences on performance expectation variables that were identified between the conditions with information (technical information, simplified technical information and conventional information). 
Table 3 - Results of the Analysis of Variance for the variables related to performance expectation

\begin{tabular}{l|r|c}
\hline \multicolumn{1}{c|}{ VARIABLE } & \multicolumn{1}{c|}{ F } & SIG. \\
\hline Less noise from neighbors & 11.462 & 0.000 \\
No leaks & 5.197 & 0.001 \\
Highly durable finishing & 4.127 & 0.007 \\
\hline
\end{tabular}

Figure 7 - Difference of the means of the variable related to Performance Expectation

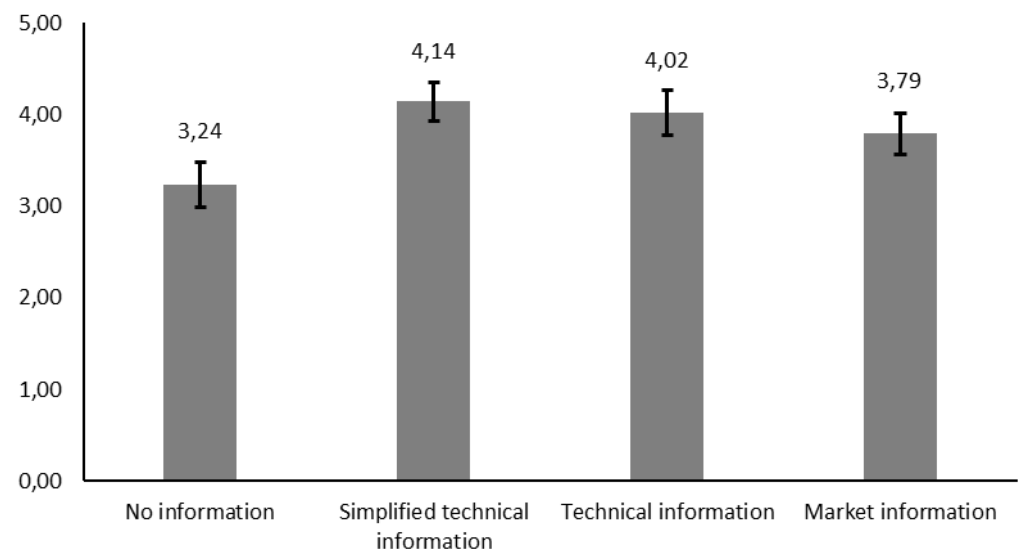

Figure 8 - Difference of the means of the variable related to Performance Expectation

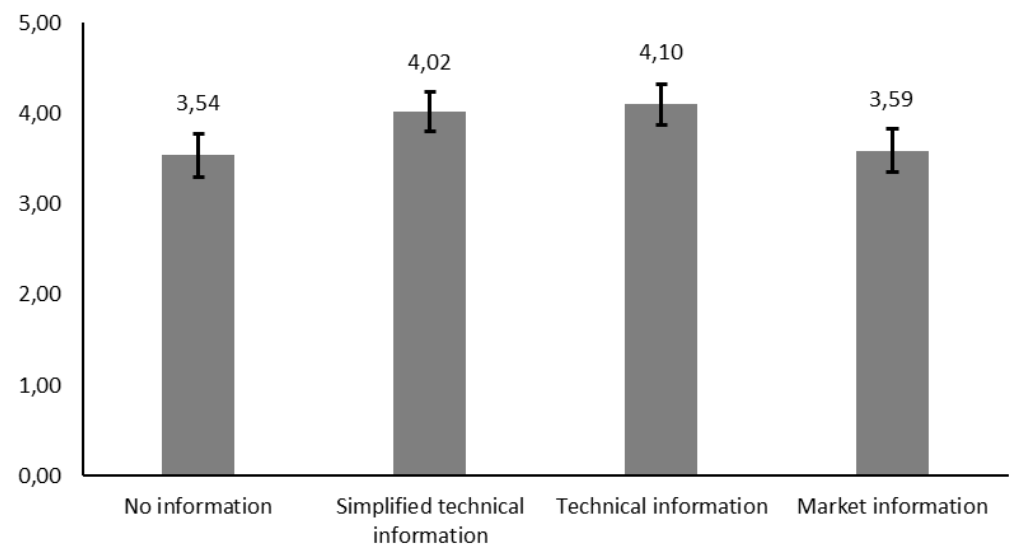

Figure 9 - Difference of the means of the variable related to Performance Expectation

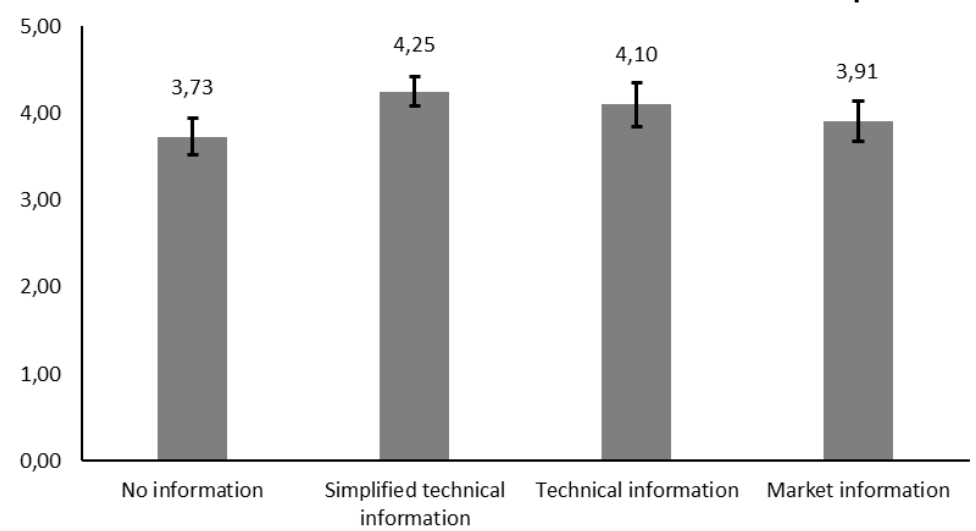




\section{Discussion}

By cross-checking the perceptions of the consumers interviewed in the exploratory study, the lack of technical information for customers during the purchasing process of a property could be identified, as well as its importance to enable greater security during the choice between the options on the market. This lack of complete information for the customer during the property purchasing process identified in this study is in alignment with reports by Gong, Lizieri, and Bao (2019), who stated that consumers are likely to use limited information during the purchase process because they do not have access to complete information and because they lack knowledge and experience.

The results of the exploratory study also suggest that consumer experience, and especially negative experiences during the use phase of the building involving problems regarding acoustics, watertightness and the quality of finishing materials, may indicate the most relevant items to be communicated to the consumer at the time of sale, and also where the construction companies should put the greatest efforts to ensure the quality of their product.

The experimental phase of the study showed that presenting information in an advertisement during the sales process of a property influences purchase intention and performance expectation, regardless if this is technical, simplified technical or market information. However, the content of the information did not have a significant difference. This result may be in line with Buckland's (1991) statement that the act of informing modifies the consumer's knowledge, decreasing uncertainties about the purchase and, consequently, altering their behavior in relation to the product.

The results of the experimental study showed that the mean of the dependent variables, purchase intention and performance expectation, of the experimental groups in which information about the property was presented (Ads 2, 3 and 4), did not promote a significant difference among themselves. That is, the means between the treatments were not statistically different.

It should be noted that the purchase intention was higher in the experimental groups in which ads 3 and 4 were presented. That is, of the four experimental groups evaluated, there was a significant and positive evolution in the purchase intention only in the group with simplified technical information (Ad 3) and market information (Ad 4). In the group subjected to the ad without information (Ad 1), a significant reduction in purchase intention could be observed. These results reinforce the statement by Tariq et al. (2013) that purchase intention is positively influenced by some independent variables, such as brand image, product quality, product knowledge, product engagement, product attributes, and brand loyalty.

In summary, the results obtained in all analyses showed that the purchase probability and the consumer's performance expectation in relation to the property advertised with information were always higher, regardless if this information was technical or typical real estate market information, which shows the importance of information in the stages that precede the purchase of a property.

\section{Conclusions}

The current study presents an empirical effort to examine the effects of the technical information of a property on both performance perceptions and purchase intentions in the real estate market. Consequently, the results reported here represent an important step toward revealing the relationships of information content in an advertisement with consumer performance expectations and purchase intentions.

This study therefore sought to identify and understand the effect of technical information applied to marketing actions through real estate advertisements in the real estate market. The results obtained in this work corroborated that providing information to the consumer during the property purchasing process impacts the buying behavior of consumers with regard to purchase intention and performance expectation, but the content of the information did not have significant difference.

In the exploratory study, the objective was to obtain a better understanding of the Purchase Decision Process (PDP) of a real estate property, mainly in the information search, alternative evaluation and post-purchase evaluation steps. In this last step, the post-purchase evaluation, the consumers reported dissatisfactions, or problems and failures, which were used to identify the requirements of the Brazilian Performance Standard (ABNT, 2013) that were used as technical information and supported the development of the conditions of the independent variable. Through the exploratory study, it was found that the respondents lacked knowledge about the product they were buying but were very interested in more information for their next purchase. 
In the experimental study, the objective was to identify the effect of technical information on the consumers' purchase intention and performance expectation. By analyzing the results, it was possible to verify that information provided in a real estate advertisement, regardless if it is technical, translated or market information, influences purchase intention and performance expectation when compared to an advertisement that has no information. It was also verified that not having information decreases purchase intention and performance expectation, and this may negatively influence a property advertised in the real estate market.

The objective of this research was to analyze the influence of the technical information of a property on the consumer's purchase intention and performance expectation. However, technical information did not have a significant influence on consumer purchase intention and performance expectation; that is, the content of the information provided to the consumer did not have a significant effect.

The study also identified which information influences consumer performance expectation in the purchase decision process. The results indicated that the acoustic performance characteristics (I believe that this apartment will have less noise from neighbors), water tightness (I believe that this apartment will not have leaks) and durability and maintainability (I believe that the finishing of this apartment will be highly durable) had a significant effect on the conditions of the independent variable.

It is believed that because the buying behavior of a property is considered complex and happens in a comparative way, as has been shown by Campos Júnior, Infante and Alexandre (2008), the study could also have happened with the participants being able to compare the advertisements. Consequently, this would have enabled the measurement of the effect of the information content. Even though no significant effect of the technical information was found on the consumers' purchase intention and performance expectation, this work is considered a starting point and not a definitive conclusion on the subject in question.

The current work did not seek to exhaust the existing literature on the subject, much less to make a complete review of the influence of technical information on the property purchasing process. Based on the studied literature, one can see that there is a lack of research in the scientific scenario on the influence of the technical information of a property when it is provided to the consumer during the purchase process in the real estate market.

This study was limited by the employment of the user requirements listed in the Brazilian Performance Standard (ABNT, 2013) as technical information of the properties, which are mandatory requirements for all residential buildings. Therefore, this study did not consider market segmentation, i.e., the respondents' income, the standard of the property, whether the purchase was made to live or invest.

This work sought to contribute to the understanding of the influence of a property's technical information, applied to the marketing actions in the real estate market and, consequently, ensuring quality information to the consumer. After reaching the current stage, it is believed that it is necessary to delve deeper in this research, analyzing several types of information on different types of real estate in a comparative way. This study opens up the field for future research that could be conducted to generalize the findings of this work with real estate advertisements, provided that the analysis happens in such a way that the consumer can compare the content of information provided in the advertisement.

In conclusion, it is clear that technical information of a property, when present in an advertisement, is an important determinant of the consumer's purchase intention and performance expectation. The relative effect of the technical information variable on the performance expectations and purchase intentions of a property clearly warrants further research, as does its effects on the actual choice.

\section{References}

ALMEIDA, A. R. D. de; BOTELHO, D. Antecedentes da satisfação no setor imobiliário. Revista de Administração de Empresas, v. 48, n. 2, p. 08-21, 2008.

ALMEIDA, H. S. de; TOLEDO, J. C. de. Qualidade total do produto. Produção, v. 2, n. 1, p. 21-37, 1992.

ALVARENGA, M. Z.; ZANQUETTO FILHO, H. Atributos intrínsecos e extrínsecos dos imóveis na grande Vitória-ES: divergências e convergências na visão dos consumidores e corretores. In: CONGRESSO

NACIONAL DE EXCELÊNCIA EM GESTÃO, 11., Rio de Janeiro, 2015. Anais [...] Rio de Janeiro, 2015.

ASSOCIAÇÃO BRASILEIRA DE NORMAS TÉCNICAS. NBR 15575-1: edificações habitacionais: desempenho. Rio de Janeiro, 2013. 
BABATUNDE, T. O.; AJAYI, C. A. The impact of information and communication technology on real estate agency in Lagos Metropolis, Nigeria. Property Management, v. 36, n. 2, p. 173-185, 2018.

BLACKWELL, R. D.; MINIARD, P. W.; ENGEL, J. F. Comportamento do consumidor. 9. ed. São Paulo: Pioneira Thomson Learning, 2005.

BLOCK, L.; KRAMER, T. O efeito de crenças supersticiosas nas expectativas de desempenho. Revista da Academia de Ciências de Marketing, v. 37, n. 2, p. 161-69, 2009.

BRASIL. Lei $\mathbf{n}^{\mathbf{0}} \mathbf{. 8 . 0 7 8}$, de 11 de setembro de 1990. Código de Defesa do Consumidor, que dispõe sobre a proteção do consumidor e dá outras providências. Brasília, 1990. Available in: http://www.planalto.gov.br/ccivil_03/Leis/L8078.htm. Access on: 10 oct. 2018.

BUCKLAND, M. K. Information as thing. Journal of the American Society for Information Science, v. 42, n. 5, p. 351-360, 1991.

CAMPOS JÚNIOR, G. B.; INFANTE, V. S.; ALEXANDRE, M. L. Motivação para mobilidade residencial e satisfação do consumidor: um estudo comportamental de marketing no mercado local de imóveis.

Interface, Natal, v. 5, p. 169-186, 2008.

CHURCHILL JUNIOR, G. A.; SURPRENANT, C. An investigation into the determinants of customer satisfaction. Journal of Marketing Research, v. 19, n. 4, p. 491-504, 1982.

CLARK, W. A. V.; LISOWSKI, W. Decisions to move and decisions to stay: Life course events and mobility outcomes. Housing Studies, v. 32, n. 5, p. 547-565, 2017.

DANTAS, M. L. Composto mercadológico de imóveis residenciais: uma análise do ponto de vista do incorporador e do cliente. Florianópolis, 2000. 165 f. Dissertação (Mestrado em Engenharia) - Programa de Pós-Graduação em Engenharia de Produção e Sistemas, Universidade Federal do Estado de Santa Catarina, Florianópolis, 2000.

DODDS, W. B.; MONROE, K. B.; GREWAL, D. Effects of price, brand, and store information on buyers' product evaluations. Journal of Marketing Research, v. 28, n. 3, p. 307-19, 1991.

FORNECK, G. C. et al. Principais fatores que geram informações técnicas de produto incompletas: o caso de uma empresa de bens de capital. In: SIMPÓSIO DE EXCELÊNCIA EM GESTÃO E TECNOLOGIA, 8., Resende, 2011. Anais [...] Resende, 2011.

GOMES, J. E. V. Avaliação do desempenho de edifícios segundo a norma NBR 15575: adaptação ao caso de edifício reabilitado. Porto, 2015. 85 f. Dissertação (Mestrado em Engenharia Civil) - Curso de Engenharia Civil, Universidade do Porto, Porto, 2015.

GONG, C. M.; LIZIERI, C.; BAO, H. X. H. Smarter information, smarter consumers? Insights into the housing market. Journal of Business Research, v. 97, p. 51-64, 2019.

GONZAGA, L. M. R. Contribuição para o aumento do nível de precisão das avaliações imobiliárias através da análise das preferências do consumidor. Porto Alegre, 2003. 145 f. Dissertação (Mestrado em Engenharia Civil) - Programa de Pós-graduação em Engenharia Civil, Universidade Federal do Rio Grande do Sul, Porto Alegre, 2003.

GUIMARÃES FILHO, A. C. C. Análise do processo de compra e venda de imóveis residenciais urbanos no Brasil: uma proposta para redução de atritos. Brasília, 2019. 203 f. Dissertação (Mestrado Profissional em Governança, Tecnologia e Inovação) - Universidade Católica de Brasília, Brasília, 2019.

HOWARD, J. A.; SHETH, J. N. The theory of buyer behavior. New York: 63, 1969.

KOKLIC, M. K.; VIDA, I. A strategic household purchase: consumer house buying behavior. Managing Global Transitions, v. 7, n. 1, p. 75-96, 2009.

KOTLER, P.; KELLER, K. L. Administração de marketing. 12. ed. São Paulo: Pearson Prentice Hall, 2006.

MACHADO, F. O. Avaliação simultânea dos determinantes de satisfação do usuário de imóveis residenciais: estudos de casos no segmento Classe Média da Região Metropolitana do Recife/PE. Pernambuco, 2005. 173 f. Dissertação (Mestrado em Engenharia de Produção) - Programa de PósGraduação em Engenharia de Produção, Universidade Federal de Pernambuco, Recife, 2005. 
MARTINS, J. C. et al. Desempenho de Edificações Habitacionais: guia orientativo para atendimento à norma ABNT NBR 15575/2013. 2. ed. Fortaleza: Gadioli Cipolla Comunicação, 2013. Câmara Brasileira da Indústria da Construção.

MOWEN, J. C.; MINOR, M. S. Comportamento do consumidor. São Paulo: Prentice Hall, 2003.

NOBRE, J. A. P.; SANTOS, A. P. S.; BARROS NETO, J. P. O desenvolvimento de produto na construção civil: um estudo de caso em Fortaleza. In: ENCONTRO NACIONAL DE ENGENHARIA DE PRODUÇÃO, Florianópolis, 2004. Anais [...] Florianópolis: ENEGEP, 2004.

OKAMOTO, P. S. Os impactos da norma brasileira de desempenho sobre o processo de projeto de edificações residenciais. São Paulo, 2015. 160 f. Dissertação (Mestrado em Engenharia Civil) - Escola Politécnica, Universidade de São Paulo, São Paulo, 2015.

OLANREWAJU, A.; WOON, T. C. An exploration of determinants of affordable housing choice. International Journal of Housing Markets and Analysis, v. 10, n. 5, p. 703-23, 2017.

OLIVEIRA, M. C. G. de; HEINECK, L. F. M. Caracterização da satisfação do usuário: proposições conceituais e metodológicas para o marketing imobiliário. In: SIMPÓSIO BRASILEIRO DE GESTÃO DA QUALIDADE E ORGANIZAÇÃO DO TRABALHO, Recife, 1999. Anais [...] Recife: UFPE, 1999.

OLIVER, R. L. A cognitive model of the antecedents and consequences of satisfaction decisions. Journal of Marketing Research, v. 17, n. 4, p. 460-469, 1980.

OLIVER, R. L. Cognitive, affective, and attribute bases of the satisfaction response. Journal of Consumer Research, v. 20, p. 418-30, dec. 1993.

PACANHAN, M. N. et al. Marketing imobiliário: uma abordagem preliminar do marketing mix no mercado de Londrina. In: SEMINÁRIO INTERNACIONAL DA LATIN AMERICAN REAL ESTATE SOCIETY, 4., São Paulo, 2004. Anais [...] São Paulo, 2004.

PANSARI, A.; KUMAR, V. Customer engagement: the construct, antecedents, and consequences. Journal of the Academy Marketing Science, v. 45, p. 294-311, 2017.

PATTERSON, P. G. Expectations and product performance as determinants of satisfaction for a high involvement purchase. Psychology \& Marketing, v. 10, n. 5, p. 449-465, 1993.

PAZ, R. R. C. B.; NOBRE, L. H. N.; NOBRE, F. C. Determinantes de preços no mercado imobiliário à luz do modelo hedônico. Revista Gestão em Análise, v. 9, n. 2, p. 60-70, 2020.

REZVANI, S. et al. A conceptual study on the country of origin effect on consumer purchase intention. Asian Social Science, v. 8, n. 12, p. 205-15, 2012.

RIBEIRO, J.; SOUZA, F. N.; LOBÃO, C. Saturação da análise na investigação qualitativa: quando parar de recolher dados? Revista Pesquisa Qualitativa, v. 10 n. 6, p. ii-vii, abr. 2018.

SIQI, Z.; HONGYU, L.; LEE, R. Buyer search and the role of broker in an emerging housing market: a case study of Guangzhou. Tsinghua Science and Technology, v. 11, n. 6, p. 675-85, 2006.

SOLOMON, M. R. O Comportamento do consumidor: comprando, possuindo e sendo. 11. ed. Porto Alegre: Bookman, 2016.

TARIQ, M. I. et al. Customer perceptions about branding and purchase intention: a study of FMCG in an emerging market. Journal of Basic and Applied Scientific Research, v. 3, n. 2, p. 340-47, 2013.

TAVARES, F. A.; MOREIRA, A. A.; PEREIRA, E. T. Assimetria de informação no mercado imobiliário em Portugal. Revista de Administração da UNIMEP, v. 11, n. 3, p. 196- 220, set./dez. 2013.

WISSENBACH, T. C. A cidade e o mercado imobiliário: uma análise da incorporação residencial paulistana entre 1992 e 2007. São Paulo, 2008. 142 f. Dissertação (Mestrado em Geografia) - Universidade de São Paulo, São Paulo, 2008.

WONG, S. Y. et al. Improving information gathering and distribution on sustainability features in the Australian residential property market. Journal of Cleaner Production, v. 184, n. 20, p. 342-52, May 2018.

WU, J. et al. Green purchase intentions: an exploratory study of the Taiwanese electric motorcycle market. Journal of Business Research, v. 68, n. 4, p. 829-33, 2015. 
ZAKARIA, Z. et al. Factors in determining the purchase intention of housing property: a study in Terengganu. In: MACFEA NATIONAL SEMINAR, 19., Malásia, 2015. Proceedings [...] Malásia, 2015.

ZINAS, B. Z.; JUSAN, M. B. M. Housing choice and preference: theory and measurement. ProcediaSocial and Behavioral Sciences, v. 49, p. 282-92, 2012.

\section{Francieli Vargas Dalbosco}

Programa de Pós-Graduação em Engenharia Civil | IMED - Politécnica | Rua Senador Pinheiro, 304, Bairro Rodrigues | Passo Fundo - RS Brasil | CEP 99070-220 | Tel.: (54) 3045-6100 | E-mail: francielidalvar@gmail.com

\section{Elvira Maria Vieira Lantelme}

Programa de Pós-Graduação em Engenharia Civil | IMED - Politécnica | E-mail: elvira.lantelme@imed.edu.br

\section{Eduardo Rech}

Programa de Pós-Graduação em Administração | IMED - Business School | E-mail: eduardo.rech@imed.edu.br

\section{Ambiente Construído}

Revista da Associação Nacional de Tecnologia do Ambiente Construído Av. Osvaldo Aranha, $99-3^{\circ}$ andar, Centro

Porto Alegre - RS - Brasil

$$
\text { CEP } 90035-190
$$

Telefone: +55 (51) 3308-4084

www.seer.ufrgs.br/ambienteconstruido www.scielo.br/ac

E-mail: ambienteconstruido@ufrgs.br 